\title{
teachers as gardeners: thinking, attentiveness and the child in the community of philosophical inquiry.
}

patricia hannam ${ }^{1}$

hampshire county council, university of winchester, united kingdom

\begin{abstract}
Biesta raises questions about the relationship between thinking and education. He wonders whether there are dimensions of education that cannot occur through the advancement of thought alone. In this paper I consider this prospect in relation to the community of philosophical enquiry and also take up Biesta's comment about liking gardens in schools. This is not in order to assert a particular analogy between gardens and gardening and the school and teaching, but rather to explore the possibility of there being practical resemblances between the existence of a garden and the human activity of gardening, and how a school should exist and the kinds of activities taking place in schools. By the close of this short paper I will have opened for further discussion the possibility that there may be some resemblances between what teachers and gardeners need to do, for example the attentiveness to uniqueness as well as creative forces outside human control. I show there is already an awareness of these concerns present in Ann Sharp's writing and close by discussing the implications for this in terms of the role of the teacher in the community of philosophical inquiry.
\end{abstract}

keywords: thinking; education; attention; uniqueness.

\section{professores como jardineiros: pensamento, atenção e a criança na comunidade de investigação filosófica.}

resumo

Biesta levanta questões sobre a relação entre o pensamento e a educação. Ele questiona-se sobre se existem dimensões da educação que não podem ocorrer apenas pelo desenvolvimento do pensamento. Neste artigo considero esta perspectiva em relação à comunidade de investigação filosófica, e também incorporo o comentário de Biesta sobre gostar de jardins em escolas. Isto não é usado para afirmar uma analogia particular entre os jardins e jardineiros e as escolas e professores, mas sim para explorar a possibilidade de existirem similitudes práticas entre a existência de um jardim e a atividade humana de jardinar, e como uma escola deveria existir e quais as atividades que deveriam ter espaço nela. Ao final deste curto artigo terei aberto, para uma discussão adicional, a possibilidade de que possam haver similitudes entre o que professores e jardineiros precisam fazer, por exemplo, a atenção à singularidade assim como às forças criativas fora do controle humano. Mostro que já existe uma consciência a respeito destas considerações, presente na escrita de Ann Sharp, e termino discutindo as implicações disso em termos do papel do professor na comunidade de investigação filosófica.

palavras-chave: pensamento; educação; atenção; singularidade.

\footnotetext{
${ }^{1}$ E-mail: thinkingworlds@yahoo.co.uk 
teachers as gardeners: thinking, attentiveness and the child in the community of philosophical inquiry.

\section{los maestros como jardineros: el pensamiento, la atención y el niño en la comunidad de la investigación filosófica.}

resumen

Biesta plantea preguntas sobre la relación entre pensamiento y educación. Se pregunta si hay dimensiones de la educación que no pueden ocurrir sólo con el desarrollo del pensamiento. En este trabajo considero esta perspectiva en relación con la comunidad de investigación filosófica y también tomo el comentario de Biesta sobre su gusto por los jardines en las escuelas. No lo hago para afirmar una analogía particular de los jardines y la jardinería con la escuela y la enseñanza, sino más bien para explorar la posibilidad de que haya semejanzas prácticas entre, de un lado, la existencia de un jardín y la actividad humana de jardinería y, de otro, cómo una escuela debería existir y los tipos de actividades que tienen lugar en las escuelas. Al final de este breve artículo habré abierto para una discusión adicional la posibilidad de que pueda haber alguna semejanza entre lo que los maestros y los jardineros necesitan hacer, por ejemplo, la atención a la unicidad, así como a las fuerzas creativas fuera del control humano. Demuestro que ya hay una conciencia de estas preocupaciones presente en la escritura de Ann Sharp y finalizo discutiendo las implicaciones de esto en términos del papel del maestro en la comunidad de investigación filosófica.

palabras clave: pensamiento; atención; educación; singularidad. 
teachers as gardeners: thinking, attentiveness and the child in the community of philosophical inquiry.

\section{introduction}

Biesta raises questions about the relationship between thinking and education. He wonders whether there are dimensions of education where thinking may not be sufficient; his point being that not everything happens through the advancement of thought alone. In relation to the community of philosophical inquiry with children his concern is perhaps that whilst philosophical work with children and young people seeks to nourish their thinking, it may not really reach their heart or touch their soul. In this paper I engage with these questions by taking up Biesta's comment about liking gardens in schools. This is not in order to assert a particular analogy between gardens and gardening and the school and teaching, but rather to explore the possibility of there being a practical resemblance between the existence of a garden (and I am here thinking of a vegetable garden rather than a flower garden) and the human activity of vegetable gardening, and how a school should exist and the kinds of activities taking place in schools. By the close of this short paper I want to have opened for further discussion not only the possibility that there may be some resemblances between what teachers and what gardeners need to do, for example in relation to a kind of attentiveness to uniqueness as well as creative forces outside human control. Alongside this, I show that there is already an awareness of these concerns present in Anne Sharp's writing and close by discussing the implications for this in terms of principle role of the teacher in the community of philosophical inquiry.

\section{what are gardens?}

To be sure a key characteristic of an earthly garden is that it requires there to be some kind of human interruption in the natural succession of things, in order to bring about some deliberate fruitfulness. This is as contrasted to some other kind of a thing where plants are growing unattended by human beings as in a 
teachers as gardeners: thinking, attentiveness and the child in the community of philosophical inquiry.

forest or a meadow. Where human activity is too strong, or destructive, nothing will grow; emerging shoots will be damaged and flowers and subsequent fruits lost. However where there is no intervention, the garden will be overrun by many other things apart from the desired maturing fruit (or vegetable). The gardener in this context must understand two things at least. First is that there needs to be some kind of deliberate intervention and secondly that any intervention requires an understanding about maturity and the different ways in which this manifests itself in the world. This means the gardener needs to understand how things usually exist in the world, whilst appreciating each particular example of existence (of say a tomato, apple or hazelnut) is entirely unique. Each species and variety within that species group, although needing the same quality of attention usually needs a different kind of action on the part of the gardener in each new situation. Different actions or interruption in its manner of growing are necessary in order for each to reach maturity. Take runner beans and leeks for example, whereas both need a good supply of water to thrive, runner beans need some kind of upright pole to support their growth as each individual plant is content to mingle with its neighbour, whereas leeks on the other hand need space between each plant and no external support in order to grow into maturity.

The gardener must know that the bean is the fruit of a flower, whereas a leek needs to be eaten well before it flowers. The gardener in this sense must participate with the creation of new life in a range of ways, applying understanding of the forces of nature - working with and not against this to bring about a particular desired situation, in this case vegetables. I am definitely thinking of a vegetable gardener who works without chemical fertilisers and pesticides since although gardens under such regimes may be fruitful; these have other well documented negative impacts of such interventions. I am instead referring in brief here, at other proven ways in which these things can come about. This is to recognise that a particular gardener may be informed in their gardening by one or several of these. For example in any area of the world there is likely to be traditional practices handed down from generation to generation; regarding 
fertility, knowledge of the soil and climate and ways in which some plants grow in harmony with each other and others don't. In addition in the west other forms of vegetable gardening have emerged such as organic (see for example Foster, 2014), permaculture (see for example HATHAWAY, 2015), biodynamic (see for example JACKSON, 2015) and forest gardening (see for example ASKERLUND \& ALMERS, 2016) to mention but a few. However most gardeners would acknowledge there to be biological and creative forces at work in the garden, and in which the gardener participates to bring about some additional and desired ends that would not necessarily happen by themselves. Nevertheless the gardener working with creation in a more deliberate sense (such as the gardener gardening in an organic or biodynamic, permaculture or forest garden manner) following along with the forces of nature, seeking to understand and interpret rather than dominate, control of conquer; I would say is acting in a 'weak' kind of a way.

\section{the gardens as places of creation}

Biesta, in 'The Beautiful Risk of Education' (2015), through a discussion of Caputo's 'Weakness of God', explores the creation narratives in the Book of Genesis. In discussing the second Genesis story about the Garden of Eden Biesta particularly notes Caputo's observations about creating being a risky business and that Yahweh in establishing the garden, or the whole of creation, set a kind paradoxical project where to retain the status quo the 'adults' must remain like children. However, the reality of the way things have been set up is as if it is almost inevitable that his creatures will fail' (BIESTA, 2015, p. 15). This is in contrast to the first creation story in Genesis chapter 1 where it is as if God is the source of all that is good and the human beings will know well how to continue to work in harmony with that. It is not possible for me to engage with the full discussion Biesta (2015) takes forward, but enough I hope to note that what is at stake here is that there is a choice between "'a strong metaphysical creationism' where creation is an act of unbridled power - and 'weak existential creationism' where creation is an event through which being is brought into life. The choice ... is therefore between essence and existence[...]". (BIESTA, 2015, p. 17). In bringing 
teachers as gardeners: thinking, attentiveness and the child in the community of philosophical inquiry.

this to education, Biesta raises questions regarding the distinction between subjectivity and subjectifcation. From this proceeds his interest in how the subject 'emerges' (BIESTA, 2015, p. 18) as a subject in an existential sense, into the world.

\section{teachers as gardeners}

Biesta has written most recently about education's relationship with the subject in 'The Rediscovery of Teaching' (2017); the 'main insight I wish to highlight about the existence of the subject and our existence as subject is that, to a large degree, our subject-ness is not in our own hands, which may even mean that it is not in our hands at all' (BIESTA, 2017, p. 10). His argument builds with Arendt, in what is part of a longer and complex argument, relating education into the public sphere in addition to supporting his discussions on what it is that the teacher should do. He further emphasises the importance of the fact that that 'we can never exist as subject in isolation' (BIESTA, 2017, p. 11). In other words the fact that this happens when we are together with other people is important and has strong links with Arendt's emphasis on the significance of 'action in plurality' (see for example Arendt, 1998). The teacher must have therefore an understanding of the nature of human existence, of for example how being human is a different kind of thing to a robot (vacuum cleaner) since this does not 'provide us with an adequate image of students in educational relationships' (BIESTA, 2015, p. 388). Further Biesta goes on to say that 'an altogether different 'account' of the event of teaching' (BIESTA, 2015, p.388) emerges one that is aimed at 'the establishment of an order ... that calls forth the subjectness of the student by interrupting its egocentrism, its being-with-itself and for-itself' (BIESTA, 2015, p.388). Something I could say is not unlike the vegetable gardener who in a practical sense interrupts the way a plant would grow on its own, and brings it into the world to exist in a new and different way. However this is a kind of weak interruption that requires attentiveness and patience on the part of the gardener. These dispositions to attentiveness rather than control, we could say to weak interruptions rather than to strong ones, are precisely the dispositions also necessary in a teacher. In the next section of this paper, I want to consider what Ann Sharp might have put into 
this discussion and how she would have been likely to relate this to the community of philosophical inquiry. And then, whilst bearing in mind that such a discussion can only be conjecture, to see if a theoretical position could be sketched out sufficiently linked with her work. I want to move to a position where I can suggest that perhaps thinking, although necessary in the community of philosophical inquiry is for sure not the only or even the most important thing going on and that nurturing thinking is not the most significant thing that the teacher will do.

\section{thinking, the teacher and the child(ren) in the community of philosophical inquiry}

In her essay 'A letter to a Novice' Sharp (1992) notes that an important quality of the teacher will be to 'hear' several different aspects of what is being said by the children and young people in the community of philosophical inquiry (see SHARP, 1992, p. 166). This piece is set in the context of explaining to the novice teacher working with the Lipman Novel Harry Stottlemeier's Discovery in the community of philosophical inquiry, and in many ways is rather specific to that. However, I want to offer a particular reading of some of Sharp's comments and see if it is possible to make links with Biesta's work before moving to draw some tentative conclusions. Before doing this I note that there is a significant additional point she notes when reminding the novice teacher in the community of philosophical inquiry of "the modal and political dimensions that you must be aware of at all times". (SHARP, 1992, p. 170). Sharp does this in order to emphasise that the purpose of education is not only to "transmit a body of knowledge". Sharp contrasts the community of philosophical inquiry to a traditional classroom environment emphasising that "telling" is not appropriate. She also warns against assuming that the purpose of education is about forming "persons". (SHARP, 1992, p. 170) in an instrumental way where the 'person' is understood in an objective way as particular and pre-determined kind of thing. She goes on to say that "in one sense you might say that you are encouraging similarity (mastery of tools of logic and inquiry), but in another very important sense you are encouraging uniqueness. You are encouraging people to think for 
teachers as gardeners: thinking, attentiveness and the child in the community of philosophical inquiry.

themselves within the context of the community" (SHARP, 1992, p. 170). Further, Sharp also says that "one can look at the Community of Inquiry as a means of personal and moral transformations [...]" (SHARP, 1992, p. 171) and importantly that such claims can be explained as 'as slow, progressive release from subjectivism, intellectual and social conformity, and preoccupation with the self into finding a world and the other people more and more meaningful' (SHARP, 1992, p. 171). Sharp (2007) relates Arendt's ideas in relation to visiting and plurality, emphasising the significance of acknowledging plurality the classroom Community of Philosophical Inquiry. Taking these ideas further, Sharp (2009) discusses the role of the teacher in supporting the children's inquiry in such a way so as they come to realise there is "no one single story, no one true account of how the world is" (SHARP, 2009, p.xx). But that "(a)ttentive listening, dislogue, enquiry and imaginative creativity bring many versions of the world[...]"(SHARP, 2009, p.xx).

It seems to me that Sharp is probably reaching towards, and seeking to respond to, a similar concern that Biesta expresses. I say this since they both seem to share an interest in the importance of, and also the way in which, the subject emerges into the world. Further it seems to me that Sharp would also agree that nurturing this is central to what we should anticipate the teacher doing in the community of philosophical inquiry and that this requires a particular kind of attentiveness on the part of the teacher towards to child. As Sharp phrases things, the teacher needs to be attentive to the movement of the child from a 'preoccupation with the self' towards 'finding the other people more and more meaningful'. Or as Biesta expresses it the teacher "calls forth the subjectness of the student by interrupting its egocentrism". (BIESTA, 2017, p. 388). In other words although thinking in the form of reason and reasoning is important in the community of philosophical inquiry, it is just one thing that the teacher can do. However thinking and reasoning for their own sake are not the desired end result of the community of philosophical inquiry. In other words the means, in terms of reasoning, is not the end and indeed advancing reasoning may be only one of the 
many things the teacher will do. Instead my point is that the task of the community of philosophical inquiry understood with Sharp is indeed about the child or young person moving from Subjectivism (Ann Sharp) to being aware of others and able to act in discerning ways in the world. Perhaps this relates to the idea of 'grown-upness' that Biesta (2017, p. 18) discusses and where teaching is interested in the Subject ness of students (BIESTA, 2017, p. 21) which is a proposal about education relating to existence rather than essence in precisely the way I suspect Ann Sharp was also reaching towards.

\section{can the community of philosophical inquiry be educational?}

I closing this short piece, I want to return to the image of the vegetable garden and to creativity. I want to recap my point about the necessity of gardeners attention to the uniqueness of each particular existence and to the disposition of patience needed to be attentive over time. I do want to suggest that there is a practical resemblance between this and what it is that the teacher should do. I emphasise simply that I am talking about the attentiveness of the more organic or permaculture or biodynamic kind of gardener in a vegetable in a vegetable garden and the need for them to be attentive to the particular needs of each vegetable plant need to be able each in their own way to reach maturity and be fruitful. The practical resemblances I have identified are the similarities regarding the way a teacher needs to be attentive to the emerging subjectness of the child. Although thinking maybe important sometimes in the school, so long as it is the subjectness of the child the teacher is significantly are concerned with, what the teacher has to do can only in part be about nurturing thinking, since thinking about things only and especially not alone is not what will bring this about. I have made a brief examination of some existing writing from Ann Sharp where I have sought to identify that far from being only interested in reason or reasoning it is clear that Sharp herself saw the movement of the child away from their own egocentricsm was something intended in the community of inquiry. Further that the teacher's role in the philosophical inquiry is to open a space where this can happen. Sharp alludes to this as a 'slow progressive release from subjectivism, intellectual and 
teachers as gardeners: thinking, attentiveness and the child in the community of philosophical inquiry.

social conformity and preoccupation with the self into finding the world and other people more and more meaningful (SHARP, 1991, p. 171). I give a number of different descriptions of this idea and argue with Biesta that education is about arousing the desire in another human being - a child, a student - for wanting to exist in that way.

\section{bibliography}

ARENDT, H. The Human Condition. Chicago: Chicago Press, 1998.

ASKERLUND, P.; ALMERS, E. Forest gardens-new opportunities for urban children to understand and develop relationships with other organisms. Urban Forestry \& Urban Greening, 20, pp.187-197, 2016.

BIESTA, G.J. The Beautiful risk of education. Boulder: Routledge, 2015.

BIESTA, G. The Rediscovery of Teaching: On robot vacuum cleaners, non-egological education and the limits of the hermeneutical world view. Educational Philosophy and Theory, 48(4), pp.374-392, 2016.

BIESTA, G.J. The Rediscovery of Teaching. New York:Taylor \& Francis, 2017.

FOSTER, H. Community Gardens: An Introduction to Organic Practices and Benefits. 17th Student Research Conference. Georgia's Public Liberal Arts University, April, 2014.

HATHAWAY, M. The Practical Wisdom of Permaculture: An Anthropoharmonic Phronesis for Moving toward an Ecological Epoch. Environmental Ethics, 37(4), pp.445-463, 2015.

JACKSON, M. Lunar \& biodynamic gardening: planting your biodynamic garden (No. 631.584 J13-1). London: Cico Books, 2015.

SHARP, A. A letter to a Novice: Teaching Harry Stottlemeier's Discovery. In: Sharp, A. \& Reed, G. (eds) Studies in Philosophy for Children. Philadelphia: Temple University Press, 1992.

SHARP, A.M. Let's go visiting: Learning judgment-making in a classroom community of inquiry. Gifted Education International, 23(3), pp.301-312, 2007.

SHARP, A.M. Introduction to Hannam, P. and Echeverria, E. Philosophy with teenagers: Nurturing a moral imagination for the 21st Century. London: Continuum, 2009.

received in: 12.08 .2017

accepted in: 31.08.2017 